\title{
Principles for the assessment of the safety requirements of work equipment for working at heights in electrical installations
}

\author{
Georgeta Buica ${ }^{1, *}$, and Constantin Beiu ${ }^{1}$ \\ ${ }^{1}$ INCDPM „Alexandru Darabont”, Electrical and Mechanical Risks Laboratory, 35A \\ Blvd, Bucharest, Romania
}

\begin{abstract}
The work in electrical installations requires some activities to be carried out on heights, and must be carried out in a safe manner and with appropriate ergonomic conditions, by choosing specific work equipment and means of protection, to ensure optimal working conditions in safety parameters. The use of electrical insulating work equipment for temporary work on heights it is a mandatory technical and safety measure to carry out the specific activities in electrical installations, as well as to ensure the protection against electrical risks and to prevent falling from heights. The research study aimed at identifying the specific professional risks and the assessment of the technical and safety requirements for work equipment intended to be used on heights - ladders made of electrical insulating material sections. Effective management of the safety management of this work equipment is necessary to ensure a high level of safety for workers and to establish the necessary preventive measures for the use of combined ladders. The results of the study consist of identifying and establishing the specific safety requirements specific to work equipment for work on heights, ladders which have both metallic and electrical insulating material.
\end{abstract}

\section{Introduction}

Electrical installations are usually located at heights and include a vast area of lighting installations, both in the construction and installation phase, during operation and maintenance, as well as on industrial buildings (halls, chimneys, towers cooling systems) or civil buildings (blocks, houses), metal constructions (cranes, bridges, walkways or pillars) and overhead power lines.

It is common to all these jobs to combine the risks specific to work at heights with the electrical risks, to which can be added the risks generated by the outdoor or indoor work environment.

The access and work can be done using scaffolding, nacelles, winches or lanes, as well as different types of ladders and rope system technique. The choice of the most efficient way of access to heights and work equipment for work at heights must be made according

\footnotetext{
${ }^{*}$ Corresponding author: gbuica@protectiamuncii.ro
} 
to the height of the task, the duration of the work, the type of work, the frequency of movement and, in case of imminent danger, the mode of evacuation.

The use of scaffolding, nacelles and other systems and collective protection measures must be the first option, according to the provisions of art. 7, par. 2, lit. $\mathrm{h}$ of the Law on Safety and Health at Work no. 319/2006 and Article 4, paragraph (2), corroborated with the provisions of Annex no. 2, art. 4.1.1.1. from EO no. 1146/2006, and depending on identified risks, supplemented with individual protective equipment.

The most labour-intensive work equipment for access to height is portable ladders and lifting equipment and nacelle equipment. Ladders cannot be used as workstations at height unless under or in accordance with art. 4.1 .1 of Annex no. 2 from EO no1146/2006. The use of other safer work equipment is not justified due to the low level of risk either due to the short duration of use or because of the existing job features and cannot be changed by the employer [1]. According to the EN 131-1 standard definition, ladders are stepping devices that a person can climb or lower. [2] Ladders can be made of various materials: wood, aluminium alloy, glass fibber, composite materials, rope, metallic cable.

In operation, different types of ladders are used: portable ladders supported by two stiles and a different number of rungs, leaning ladders consisting of two or more sections, double ladders, transformable / multifunctional ladders, modular ladders, electrical insulating ladders.

Electrical insulating ladders can be entirely made of insulating materials or have a combined construction of conductive elements and insulating elements. From a functional point of view, national standard SR EN 61478 divides electrical insulating ladders into two categories. Category 1 ladders are designed to be positioned vertically on pillars, leaning on them, standing either on the ground or on a special platform fixed to the pillar. These ladders must have at least one electrical insulating part. Category 2 ladders are designed for live working, to allow access to active parts in a horizontal, vertical or inclined position. [3]

\section{Aspects regarding the analysis and evaluation of electrical insulating ladders in use in electrical installations}

Studies on the assessment of the occupational risk and occupational disease and the studies conducted to establish the requirements and methods necessary for the technical and safety tests of protective equipment for live working in electrical installations, electrical power stations and high voltage overhead lines for transmission and distribution of electric power, or in the electric power stations and substations of a wind farm or a series of electric power users, have highlighted the risk factors due to the work equipment for work at height electrical insulating ladders and combined ladders, as well as the risk factors generated by users of work equipment for work at height.

Approximately $21 \%$ of the ladders in use had the anti-slip devices (lower and upper) missing or damaged. The same nonconformities have also been identified in the adjustable systems used in the execution of work on an uneven ground / working plane. $17 \%$ of the ladders exhibited mechanical damage to both the stiles and the rungs and the locking / safety devices. $6 \%$ of the assessed ladders did not have anchorages / safety systems, or if they existed were incomplete or damaged. There have also been identified non-compliances with sections of locking systems and safety systems against opening, some of which are damaged and repaired by users without the consent of manufacturers or distributors, violating the provisions set out in the Technical Paper of the product.

The evaluation of technical condition for ladders also took into account the content of their technical documents (technical paper / instructions for use), of which $37 \%$ have no technical documents or they are not in conformity with the applicable regulations, 
respectively $41 \%$ of the evaluated equipment were not tested periodically by visual examination and dielectric testing.

The purpose of the analysis of the safety level assessment is to provide the opportunity to know the real situation from the point of view of safety and to take the proper prevention methods for the given situation. [4]

In fig. 1, the technical and compliance status of electrical insulating ladders and combined ladders in use is presented.

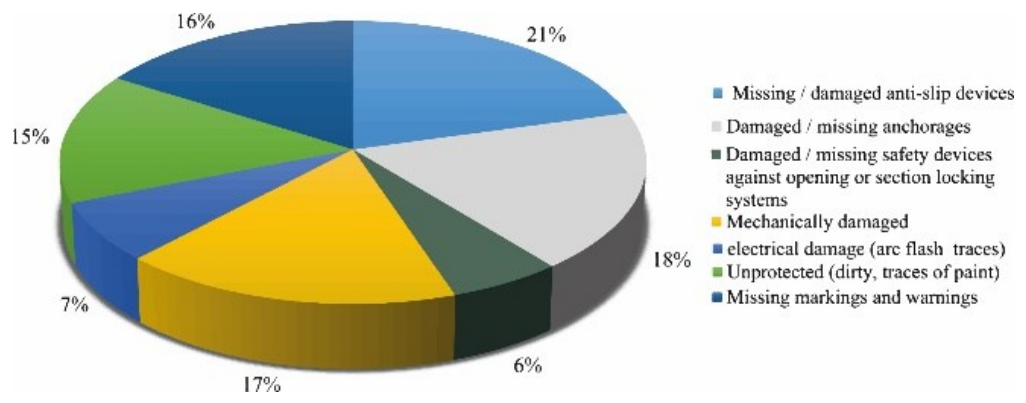

Fig. 1. Analysis of technical and compliance status of electrical insulating ladders and combined ladders in use

The evaluation of the ladders in use was also performed through the user point of view and the occurrences of accidents and work-related accidents. The unsecured factor of top or base of the ladders has the highest percentage of $19 \%$, followed by the non-assurance of the safety distances to electrical installations or parts of the electrical installations, $18 \%$, the incomplete evaluation of the work area and the support area (fragile, slippery, unstable) $14 \%$, non-compliance with ladders specifications (non-insurance against falls, use of inappropriate lengths ladders, failure to ensure the maximum permissible load, inappropriate use or of section locking systems or non-opening safety systems, failure to observe the angle of inclination of single or extended ladders) by $13 \%$ or failure to ensure the material boundary of the work area, respectively signalling and / or blocking access ways.

Analysing the weight of the identified factors, we find that the mechanical, electrical, wrong actions, and omissions have the greatest weight. In this respect, a rigorous analysis of the causes that generate these factors and, in particular, the electrical problems from all activities in order to identify the electrical hazards that may occur and cause serious injuries or even the death of workers involved in the working process. [5]

An analysis of the causes of occupational accidents during operational use of ladders argues the need to address prevention and protection from a new perspective, taking into account the general principles of prevention as laid down by Law no. 319 / 2006 on safety and health at work. [6]

\section{The technical and safety requirements specific to the work equipment category for work at height - electrical insulating ladders and ladders incorporating sections of insulating material}

Work equipment for work at height - electrical insulating ladders and ladders with insulating material sections must meet the requirements of EO no.1146 / 2006 on minimum health and safety requirements for the use of work equipment by workers at work; the 
applicable national and European standards and the Safety and Health at Work guidelines for in-service electrical installations.

The compliance of the electrical insulating ladders and the ladders with insulating material sections is attested by the guarantee of the conditions stipulated by art. 3 (4) of the Law no. 245/2004, following the conformity assessment taking into account:

a) non-binding national standards transposing relevant European standards other than harmonized standards for products covered by the CE marking;

b) standards established in the state in which the product is sold;

c) guidance on product safety assessment;

d) good practice factsheets for product safety in the sector concerned;

e) the present state of scientific and / or technical knowledge

f) reasonable consumer expectations regarding general product safety. [7]

When determining the technical and safety requirements applicable to electrical insulating ladders and ladders incorporating insulating material sections, besides the legislative and technical provisions, have taken in to account the conditions of use (field of use, precautions in use, mode of use, maintenance, storage and transport) and technical characteristics (dimensional, electrical, mechanical, thermal) [8], corroborated with the results of the studies carried out on the assessment of the occupational risk and occupational disease level and the studies carried out on the establishing requirements and methods necessary for the technical and safety tests of protective equipment for work in live electrical installations.

Taking into consideration the mechanical stresses in use (strength, bending, torsion and flexion, dynamic and static shock due to fall electrical insulating ladders and ladders designed for use in electrical and telecommunication installations have to ensure a strength appropriate to these stresses. [9] It also took into account the provisions of art. 23 and 24 of the Order no. 23/2011 of National Energy Regulatory Authority (ANRE) for the approval of the Technical Norm regarding the establishment of requirements for execution of live working in electrical installations. Table 1 presents the minimum technical and safety requirements applicable to electrical insulating ladders and ladders which consist of sections of insulating material.

Table 1. Technical and safety requirements applicable to electrical insulating ladders and ladders incorporating sections of insulating material [1-2, 8 - 13]

\begin{tabular}{|c|c|c|c|c|c|c|}
\hline \multirow[t]{3}{*}{$\mathrm{S} / \mathrm{N}$. } & \multirow{3}{*}{$\begin{array}{l}\text { Technical and safety } \\
\text { requirements for work } \\
\text { equipment }\end{array}$} & \multirow{3}{*}{$\begin{array}{l}\text { Legal } \\
\text { provision } \\
\text { EO no. } \\
1146 / 2006\end{array}$} & \multirow{3}{*}{$\begin{array}{c}\text { Objectives } \\
\text { assimilated } \\
\text { from EO } \\
\text { no. } \\
409 / 2016\end{array}$} & \multicolumn{3}{|c|}{ Test condition } \\
\hline & & & & \multicolumn{2}{|c|}{ SR EN 61478} & \multirow{2}{*}{$\begin{array}{c}\text { SR EN } \\
131- \\
2+\mathrm{A} 2\end{array}$} \\
\hline & & & & $\begin{array}{c}\text { category } \\
1\end{array}$ & $\begin{array}{l}\text { category } \\
2\end{array}$ & \\
\hline 1. & $\begin{array}{l}\text { component materials, } \\
\text { insulating materials }\end{array}$ & 4.1.1.1 & - & \multicolumn{2}{|c|}{$\begin{array}{l}\text { SR EN } 60855 \\
\text { SR EN } 61235\end{array}$} & 4.2 \\
\hline 2. & $\begin{array}{l}\text { physical (design, } \\
\text { dimension, surface finish, } \\
\text { rungs) }\end{array}$ & 4.1 .1 .1 & - & 6.2 & 6.2 & $\begin{array}{l}4.3,4.4, \\
4.7\end{array}$ \\
\hline 3. & $\begin{array}{l}\text { functionality (use with and } \\
\text { without protection systems } \\
\text { against falling or other } \\
\text { protective equipment } \\
\text { attached) }\end{array}$ & $\begin{array}{l}4.2 .1 \\
4.2 .2 \\
4.2 .3\end{array}$ & - & 6.2 & 6.2 & - \\
\hline 4. & mechanical & 4.1 .1 .1 & - & 6.4 & 6.4 & - \\
\hline & $\begin{array}{l}\text { - } \quad \text { strength (maximum } \\
\text { extension of ladder) }\end{array}$ & 4.1 .1 .1 & - & 6.4 .1 .2 & 6.4 .1 .2 & 5.13 \\
\hline & $\begin{array}{l}\text { - } \quad \text { strength (one } \\
\text { section, extended ladder) }\end{array}$ & 4.1 .1 .1 & - & 6.4 .1 .2 & 6.4 .1 .2 & 5.2 \\
\hline
\end{tabular}




\begin{tabular}{|c|c|c|c|c|c|c|}
\hline \multirow[t]{3}{*}{$\mathrm{S} / \mathrm{N}$. } & \multirow{3}{*}{$\begin{array}{l}\text { Technical and safety } \\
\text { requirements for work } \\
\text { equipment }\end{array}$} & \multirow{3}{*}{$\begin{array}{l}\text { Legal } \\
\text { provision } \\
\text { EO no. } \\
1146 / 2006\end{array}$} & \multirow{3}{*}{$\begin{array}{c}\text { Objectives } \\
\text { assimilated } \\
\text { from EO } \\
\text { no. } \\
409 / 2016 \\
\end{array}$} & \multicolumn{3}{|c|}{ Test condition } \\
\hline & & & & \multicolumn{2}{|c|}{ SR EN 61478} & \multirow{2}{*}{$\begin{array}{r}\text { SR EN } \\
131- \\
2+\mathrm{A} 2\end{array}$} \\
\hline & & & & $\begin{array}{c}\text { category } \\
1\end{array}$ & $\begin{array}{c}\text { category } \\
2\end{array}$ & \\
\hline & $\begin{array}{l}\text { - bending strength } \\
\text { (extended) }\end{array}$ & 4.1.1.1 & - & 6.4.1.3 & 6.4.1.3 & 5.3 \\
\hline & $\begin{array}{l}\text { - lateral deflection } \\
\text { strength }\end{array}$ & 4.1 .1 .1 & - & 6.4 .1 .4 & 6.4 .1 .4 & 5.4 \\
\hline & $\begin{array}{l}\text { - deflection strength } \\
\text { on rungs }\end{array}$ & 4.1.1.1 & - & 6.4.1.5 & 6.4 .1 .5 & 5.6 \\
\hline & $\begin{array}{l}\text { - deflection strength } \\
\text { on two connected } \\
\text { elements }\end{array}$ & 4.1.1.1 & - & 6.4 .2 .1 & - & - \\
\hline & $\begin{array}{l}\text { - deflection strength } \\
\text { on maximum extension } \\
\text { of ladder }\end{array}$ & 4.1 .1 .1 & - & - & - & 5.15 \\
\hline & $\begin{array}{l}\text { - bending resistance } \\
\text { of rungs }\end{array}$ & 4.1 .1 .1 & - & 6.4.1.6 & - & 5.7 \\
\hline & $\begin{array}{l}\text { - rung/stile assembly } \\
\text { test }\end{array}$ & 4.1.1.1 & - & 6.4.2.3 & - & - \\
\hline & - $\quad$ fixing system tests & 4.1.1.1 & - & 6.4.2.4 & - & - \\
\hline & $\begin{array}{l}\text { - the strength of the } \\
\text { extension on fitting } \\
\text { systems }\end{array}$ & 4.2 .2 & - & 6.4 .2 .5 & - & - \\
\hline & - $\quad$ cradle test & 4.1.1.1 & - & 6.4 .2 .6 & - & - \\
\hline & - tensile strength & 4.1 .1 .1 & - & - & 6.4 .3 .1 & - \\
\hline & $\begin{array}{l}\text { - } \quad \text { strength for } \\
\text { connecting devices of } \\
\text { spliced ladders and hook } \\
\text { ladders }\end{array}$ & 4.2 .2 & - & - & 6.4 .3 .2 & 5.9 \\
\hline & $\begin{array}{l}\text { - } \quad \text { strength for } \\
\text { connecting devices of } \\
\text { spliced ladders and hook } \\
\text { ladders }\end{array}$ & 4.2 .2 & - & - & 6.4.3.2 & 5.9 \\
\hline & $\begin{array}{l}\text { - lending strength in } \\
\text { horizontal position }\end{array}$ & 4.1.1.1 & - & - & 6.4 .3 .3 & - \\
\hline & $\begin{array}{l}\text { (base slip strength } \\
\text { for leaning ladders) }\end{array}$ & 4.2 .2 & - & & - & 5.18 \\
\hline & $\begin{array}{l}\text { - strength of bottom } \\
\text { stile ends }\end{array}$ & 4.1.1.1 & - & & & 5.5 \\
\hline & - mechanical ageing & 4.1.1.1 & - & $\begin{array}{l}6.4 .1 .3 \\
6.5 .1 \\
\end{array}$ & - & - \\
\hline 5. & dielectric & $\begin{array}{l}4.1 .1 .1 \\
2.19 \\
3.3 .1\end{array}$ & $2 \mathrm{a}, 2 \mathrm{~b}, 2 \mathrm{~d}$ & 6.5 .1 & - & 5.16 .3 \\
\hline \multirow[t]{4}{*}{5.1} & after mechanical ageing & \multirow{4}{*}{$\begin{array}{l}4.1 .1 .1 \\
2.19 \\
3.3 .1\end{array}$} & - & 6.5 .1 & 6.5 .1 & 5.16 .3 \\
\hline & - leakage current & & $2 \mathrm{a}, 2 \mathrm{~b}, 2 \mathrm{~d}$ & 6.5 .1 & 6.5 .1 & 5.16 .3 \\
\hline & - puncture resistance & & $2 a, 2 b, 2 d$ & 6.5 .1 & 6.5 .1 & 5.16 .3 \\
\hline & $\begin{array}{l}\text { - extreme temperature } \\
\text { condition }\end{array}$ & & $\begin{array}{l}2 \mathrm{a}, 2 \mathrm{~b}, 2 \mathrm{~d}, \\
3 \mathrm{~b}\end{array}$ & - & - & - \\
\hline \multirow[t]{2}{*}{5.2} & $\begin{array}{l}\text { after mechanical ageing } \\
\text { test and water conditioning }\end{array}$ & \multirow{2}{*}{$\begin{array}{l}4.1 .1 .1 \\
2.19 \\
3.3 .1\end{array}$} & $\begin{array}{l}2 \mathrm{a}, 2 \mathrm{~b}, 2 \mathrm{~d}, \\
3 \mathrm{~b}\end{array}$ & 6.5 .1 & 6.5 .1 & 5.16 .3 \\
\hline & - leakage current & & $2 a, 2 b, 2 d$ & 6.5 .1 & 6.5 .1 & 5.16 .3 \\
\hline
\end{tabular}




\begin{tabular}{|c|c|c|c|c|c|c|}
\hline \multirow[t]{3}{*}{$\mathrm{S} / \mathrm{N}$. } & \multirow{3}{*}{$\begin{array}{l}\text { Technical and safety } \\
\text { requirements for work } \\
\text { equipment }\end{array}$} & \multirow{4}{*}{$\begin{array}{c}\text { Legal } \\
\text { provision } \\
\text { EO no. } \\
1146 / 2006\end{array}$} & \multirow{3}{*}{$\begin{array}{c}\text { Objectives } \\
\text { assimilated } \\
\text { from EO } \\
\text { no. } \\
409 / 2016\end{array}$} & \multicolumn{3}{|c|}{ Test condition } \\
\hline & & & & \multicolumn{2}{|c|}{ SR EN 61478} & \multirow{2}{*}{$\begin{array}{l}\text { SR EN } \\
131- \\
2+\mathrm{A} 2\end{array}$} \\
\hline & & & & $\begin{array}{c}\text { category } \\
1\end{array}$ & $\begin{array}{c}\text { category } \\
2\end{array}$ & \\
\hline & - puncture resistance & & $2 a, 2 b, 2 d$ & 6.5 .1 & 6.5 .1 & 5.16 .3 \\
\hline \multirow[t]{3}{*}{6.} & chemical & \multirow[t]{3}{*}{4.1 .1 .1} & - & - & - & - \\
\hline & - resistance to solvents & & - & - & - & - \\
\hline & $\begin{array}{l}\text { - resistance to } \\
\text { penetration of the } \\
\text { paint }\end{array}$ & & - & - & - & - \\
\hline 7. & $\begin{array}{l}\text { hydrophobic surface } \\
\text { properties }\end{array}$ & 4.1 .1 .1 & - & - & - & - \\
\hline 8. & $\begin{array}{l}\text { extreme temperature } \\
\text { condition }\end{array}$ & 4.1 .1 .1 & - & - & - & 5.16 \\
\hline 9. & $\begin{array}{l}\text { corrosion resistance of } \\
\text { metal parts and accessories }\end{array}$ & 4.1 .1 .1 & - & - & - & - \\
\hline 10. & marking & - & - & $\begin{array}{l}5.6 \\
6.3\end{array}$ & $\begin{array}{l}5.6 \\
6.3\end{array}$ & $\begin{array}{l}\text { SR EN } \\
131-3 \\
5.14\end{array}$ \\
\hline
\end{tabular}

In order to meet the technical and safety requirements of electrical insulating ladders and ladders that have components of insulating material sections, the verification conditions have been identified and established.

The safety conditions were validated by tests on an insulating electrical ladder consisting of two sections made of fiberglass, an electrical insulating ladder consisting of two sections made of plastic stiles and fiberglass rungs as well as three sections sliding electrical insulating ladder made of aluminium stiles and fiberglass rungs. Tests were also carried out on a combined sliding ladder consisting of two sections of aluminium stiles and the last section having stiles made of insulating materials with aluminium rungs.

Studies on various rigid insulating materials have highlighted the influence of mechanical risk factors on the dielectric characteristics, in this sense the ladders have undergone mechanical, chemical, climatic and then electrical stresses. [9] Verification of the dielectric characteristics was performed in accordance with the laboratory testing procedures, taking into account the verification methods indicated in the applicable standards. Electrical insulating sections ladders were conditioned at total immersion in water for 24 hours, then left to dry for 4 hours in the vertical position.

The test voltage was applied for one minute on each pair of rungs and between rungs and stiles. According to SR EN 61478, the test voltage is defined according to the distance between the rungs and the ladder category.

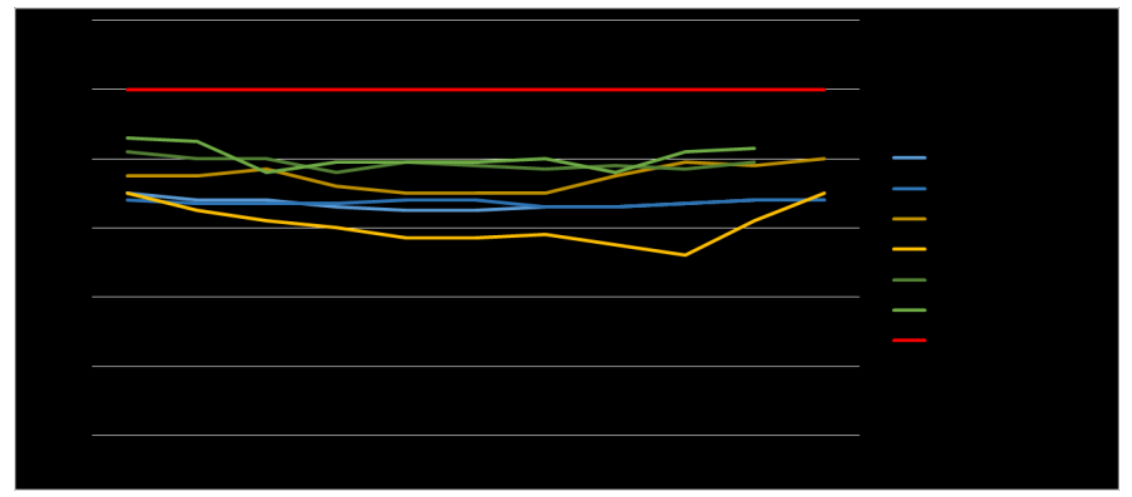

Fig. 2. Leakage current values (after conditioning) - new electrical insulating ladders 
During the tests, in addition to leakage current, the arc flashes and the local heating was taking into account. It was noticed that the samples having large losses from the dielectric characteristic also show visible local heating. [14]

Fig. 2 shows the results of dielectric characteristics of the electrical insulating sections ladders.

Fig. 3 shows the results of the dielectric characteristics tests on the last section of a combined sliding ladder. The section is made of insulating material with aluminium rungs, the dielectric rigidity test is carried out in dry condition and after conditioning to aging and immersion in water. There is a decrease in dielectric rigidity due to the mechanical stress of the material combined with the water absorption.

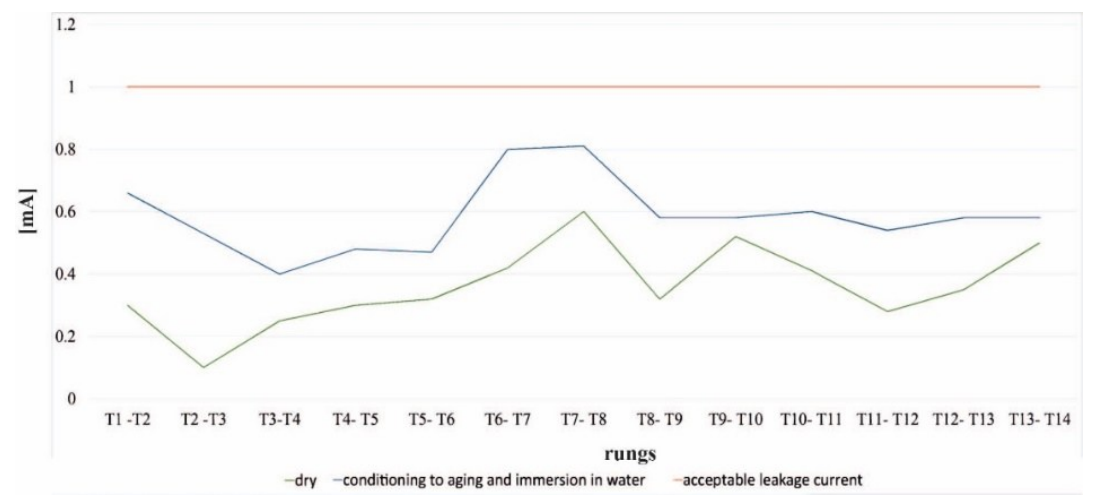

Fig. 3. Leakage current values - section made in combination with conductive elements

In fig. 4 and fig. 5 are presented the results of dielectric characteristics verification of three electrical insulating ladders consisting of two respectively one section of a combined ladders in use for about 5 years.

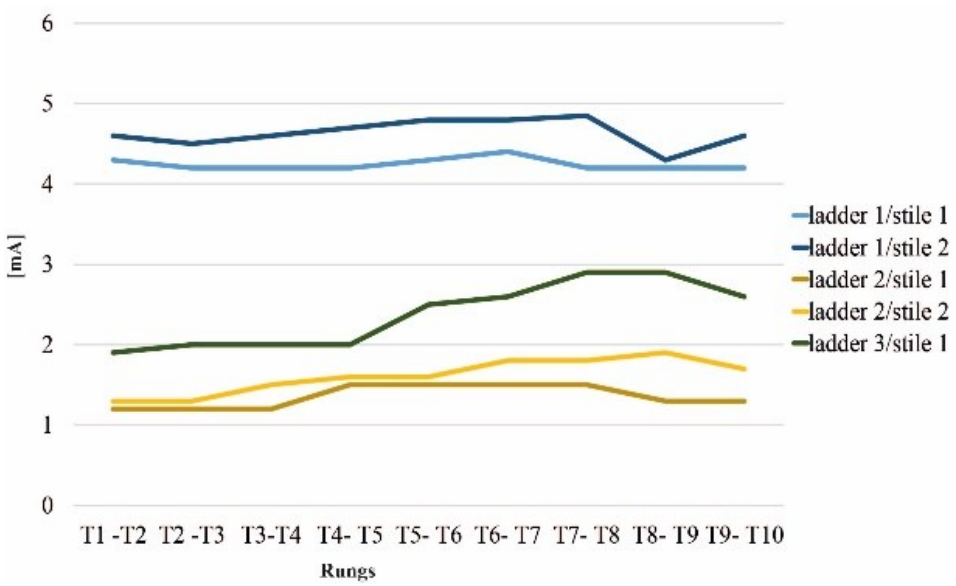

Fig. 4. Leakage current - electrical insulating ladders in use

Fig. 5 shows the results of the dielectric characteristics tests on each section of electrical insulating ladders in use for about 5 years.

Analysing the results of the tests on each section (11 rugs for each section) we observed the reduction of the dielectric characteristics in the areas most used during the execution of the works (on rugs 6, 7 and 8).

Microclimate conditions can decisively influence the safety of electrical insulating equipment in terms of insulation degradation, resulting in a higher risk for workers. [15] 


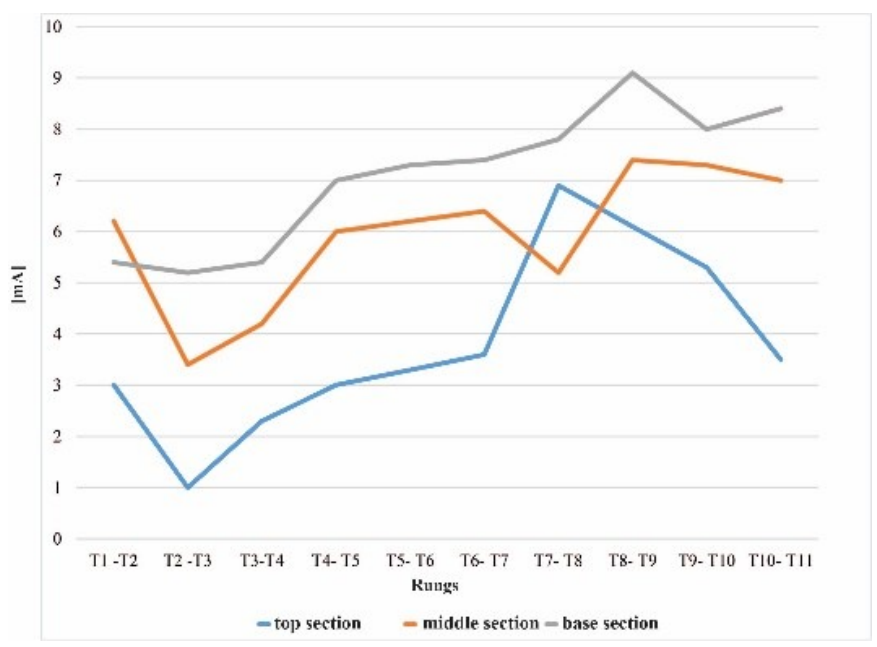

Fig. 5. Electrical leakage current - electrical insulating stile for ladders in use

It is noted, over time, the loss of dielectric characteristics as a result of the deterioration of the coatings treated by the insulating material against the penetration of dirt and water into its fibres, exposure to extreme temperatures, solar radiation as a result of the use, transport (on the car) and storage under improper conditions.

The results of the evaluation of electrical insulating ladders and ladders incorporating sections of insulating material-in use are information on how to occupational management hazards, the efficiency of selection and procurement procedures, the maintenance procedures and to establish the most appropriate technical diagnostic and inspection / control measures [8].

Effective management of safety management of electrical insulating ladders and ladders incorporating insulating material sections is required, in order to ensure a high level of safety for workers and to establish the necessary preventive measures for the use of ladders.

Measurement of insulation resistance is one of the most important periodic tests to be done to ensure the safety of workers and safety of electrical installations. The reason these tests are done is to prevent accidents caused by electric shock and damage to equipment [16].

Awareness and involvement of top management is essential in the development of organizational risk management and to increase the risk awareness at different levels of the organization [17].

Safety management of these work equipment, as well as the occupational health and safety management system are the key component which has to be integrated in the company's general management system and its implementation should be made by integration in other management systems which are relevant for the organization, such as quality, environment or social responsibility. [18].

\section{Conclusion}

Electrical insulating ladders and ladders incorporating electrical insulating material sections are work equipment designed for access to height in electrical installations whether they are live or dead. The combination of high-risk hazards with electrical hazards, plus the risks generated by the user and the work environment, requires effective management of the safety management of this work equipment by monitoring technical and safety status, including periodic verification of dielectric characteristics. 
Effective management of combined safety work equipment is necessary to ensure a high safety level of workers and to establish the necessary preventive measures for the use of these categories of ladders.

\section{References}

1. GD 1146/2006 concerning the minimum safety and health requirements for the use of work equipment by workers at work, on line at:

https://osha.europa.eu/fop/romania/ro/legislation/hotarare_1146_30_august_2006.shtml

2. SR EN 131-1:2016 Ladders - Part 1: Terms, types, functional sizes

3. SR EN 61478:2003/A1:2004, Live working - Ladders of insulating material (2004)

4. S.M. Radu, V.M. Pasculescu, Safety level assessment in potentially explosive atmospheres Recent Advances in Industrial and Manufacturing Technologies, 98-103 (2013)

5. D. Păsculescu, L. Lupu, V.M. Pasculescu, I. Inişconi, M. Suvar, Study of electrocution hazards in three-phase electrical networks with ground-isolated neutral point, EMJ, 11, No. 7, 12671271 (2012)

6. N. Băncilă-Afrim, R. I. Moraru, L.I. Cioca, G.B. Babut, Accidents at work among industrial presses operators: analysis of statistics in North-Western region of Romania, Qual.AccessSuccess 20 (S1), 19-24 (2019)

7. INCDPM, Guide for the application of GD No.1146/2006 regarding the minimum safety and health requirements for the use of work equipment by workers (in Romanian) (2013)

8. G. Buica, A.E. Antonov, C. Beiu, D. Pasculescu, M. Risteiu, Management of electrical equipment and protective devices used in electrical installations, Qual.-AccessSuccess 20 (S1), 159-164 (2019)

9. G. Buica, A.E. Antonov, C. Beiu, R. Dobra, M. Risteiu, The influence of mechanical parameters on dielectric characteristics of rigid electrical insulating material, IOP Conf. Series: Materials Science and Engineering 374 (2018)

10. GD 409/2016 - Laying down the conditions for making available on the market of low-voltage electrical equipment

11. SR EN 131-2+A2:2017, Ladders - Part 2: Requirements, testing, marking (2017)

12. SR EN 131-3:2018, Ladders - Part 3: Marking and user instructions (2018)

13. SR EN 131-4:2007, Ladders - Part 4: Single or multiple hinge-joint ladders (2007)

14. P. Dašić, C. Hutanu, V. Jevremović, R. Dobra, M. Risteiu, I. Ileana, High Accuracy Investigation of Microwave Absorption in Polymer Electrical Components on Motherboard of Computers, IOP Conf. Series: Materials Science and Engineering 209 (2017)

15. Pasculescu V.M., Vlasin N.I., Suvar M.C., Ghicioi E., Florea D., Considerations on impact resistance tests for electrical equipment used in explosive atmospheres, Proceedings of the16th International Multidisciplinary Scientific Geoconference SGEM 2016, Section Science and Technologies in Geology, Exploration and Mining, Volume II, Albena, Bulgaria, 181-188, (2016)

16. R. Dobra, D. Pasculescu, G. Marc, M. Risteiu and A. E. Antonov, Designing and Implementation a Lab Testing Method for Power Cables Insulation Resistance According with STAS 10411-89, SR EN ISO/CEI/17025/2005, IOP Conf. Series: Materials Science and Engineering 209 (2017)

17. Babut G, Moraru R, General framework for environmental risk management, Agir Bulletin 3, (2006)

18. D. Darabont, A.E. Antonov, C. Bejinariu. Key elements on implementing an occupational health and safety management system using ISO 45001 standard, MATEC Web of Conferences, 121, MSE 2017 (2017) 